the building and branch inwards along the peninsular benches.

The front door and entrance hall are located on the middle floor of the three main floors of the building. A central corridor lined with built-in coat lockers runs westward from the main east staircase to the smaller staircase at the west end. On the south side of the corridor is the large elementary teaching laboratory with associated preparation room. On the north side are students' locker rooms and lavatories, a photographic suite, tutorial and balance rooms, the main stores and the goods entrance with unloading bay.

The south-west corner of the upper floor houses the library. Next to it is the departmental office and beyond that the professor's room and laboratory. This floor contains a number of rooms for research and postgraduate instruction, including those for macromolecular biochemistry and molecular biology, cellular biochemistry and the radiochemical laboratory. A cold room, a centrifuge bay and a staff common room are also on this floor. Above it, at the east end, is the tower which contains ventilation machinery, lift machinery and a large water deionizer. The upper level of the tower houses large water storage tanks.

On the south side of the lower floor are the advanced laboratory and the honours laboratory separated by a common preparation room and instrument room. This floor also houses various groups of rooms for research and postgraduate instruction, including those for nutritional biochemistry, plant biochemistry, microbiological biochemistry and veterinary biochemistry, and at the east end, roughly underneath the front hall, are a large cold room with inner freezing compartment, an autoclave room, incubator rooms and a centrifuge bay.

At the west end of this floor a bridge communicates with the animal house in an adjacent building. On this floor also is the lecture theatre with retiring rooms and cloak rooms.

The basement floor is confined to the east end of the building. It contains a large chromatography room, an electrophoresis room, a $\mathrm{Kjeldahl} \mathrm{room,} \mathrm{an} \mathrm{isotope} \mathrm{assay}$ room, a mechanieal workshop, an electronic workshop, a large-scale preparation room, a glass wash-up room and a shower bath.
The Department has heavy teaching responsibilities in the Faculty of Medicine and in the Faculty of Science. and is believed to be the largest in Britain in terms of student numbers. Instruction is given each year to some 800 students made up approximately as follows:

Postgraduate research students

Postgraduate students attending lecture courses only (Ed.B., D. . . H., etc.)

Final honours science students

Advanced science students

Elementary science students

Medical students (2nd year)

Medical students (4th year)

Dental students

Veterinary students (2nd year)

Vharmacy students (3rd year)

On the research side, the Department concerns itself with several different aspects of biochemistry. One topic which has been under active investigation for more than 15 years is the study of the components of the mammalian cell, particularly the nucleic acids (RNA and DNA), their distribution and biosynthesis, and the part they play in the economy of the cell. For this purpose both normal and cancer cells are used as well as cells infected with viruses. For certain purposes it is desirable to study pure strains of mammalian cells, and a special unit has been set up for the large-scale production and examination of cells in culture. The chemical changes associated with cell growth and division are the subject of extensive investigation.

Biochemistry has an important bearing on the subject of human and animal nutrition, and that aspect of nutrition which is under special examination in the Department deals with protein metabolism, structure and biosynthesis.

In the investigation of plant biochemistry special attention is being directed to nitrogen fixation and aminoacid metabolism. The investigation of the chemical processes in micro-organisms includes an examination of the mode of action of antibiotics and of the way in which new enzymes are formed in bacterial cells.

Work on the biochemistry of the domestic animals in health and disease is undertaken in association with the veterinary departments of the University. Among the investigations in progress is a comparative study of immunological response in the horse, cow, sheep, pig, dog and eat.

\title{
THE CARNEGIE INSTITUTION OF WASHINGTON
}

$Y$ EAR BOOK No. 62 of the Carnegie Institution of Washington*, covering the year ended June 30, 1963, includes the report of the President, reports of the departments and special studies, with bibliographies of publications during the year, and the auditors' report.

In his review of the year, the President refers particularly to the work of the Institution on the structure and content of the cosmos, on the origin, evolution and comparative physiology of life forms, the characteristies of natural systems and on the particulate character of energy and matter to illustrate the extent to which the Institution is concerned with four of the overriding problems of to-day. At the Mount Wilson and Palomar Observatories the advances achieved during the year include the discovery of a galaxy, $3 C 273$, radiating about 100 times as much energy as the Milky Way Galaxy, as well as another powerful radiating galaxy, $3 C 48$, which may be the second most distant galaxy observed optically so far. Evidence was obtained that gigantic explosions occurring in such galaxies may be the source of the intense radiation, and the age of the Milky Way Galaxy

* Carnegie Institution of Washington. Year Book 62, 1962-1963. Pp. $\mathrm{xi}+551+13$ plates. (Washington, D.C.: Carnegie Institution of Washing
ton, 1963.) See also p. 533 of this issue of Nature. is now estimated as being about 12 billion years. Much now information has also been obtained about the circulation of the atmosphere on Venus, and the amount of water vapour in the atmosphere of Mars has been measured with high accuracy. Since this is about one two-hundredth of the amount of water in the air over desert areas like the Sahara, and about one-fourth of that in the antarctic atmosphere, it is thought that the existence of life on Mars in any form resembling that on the Earth is unlikely.

Investigations in the Geophysical Laboratory have thrown new light on the origin of petroleum. Slow decomposition, by mild heating, of kerogen--an insoluble bituminous substance resulting from the slow decay of plant and vegetable material, which is widely distributed in rocks and clays-yields saturated straight-chain hydrocarbons of a type abundant in natural petroleum. The yields of hydrocarbons from organic materials in the older rocks differ from those obtained from the kerogens of recent formations, and it is believed that the original composition of organic matter in the older rocks differed significantly from that in later formations. The major effort of the Laboratory in geochronology continued to be evaluation of the reliability of mineral ages. 
The Department of Terrestrial Magnetism continued its laboratory synthesis of minerals to obtain further understanding of the composition and structure of the Earth. Measurements, in collaboration with the University of Wisconsin, on the North Carolina oceanic shelf, of the arrival velocities of Earth waves produced by specially set explosions, using new recording-array procedures, indicated that in that area the Earth's crust is at a depth of about 22 miles. The investigations also point to the probability that the rocks in the lower part of the Earth's crust are a continuously changing mixture in which the importance of the iron-magnesium minerals in chemical composition increases with depth. In the same Department the Biophysics Group developed the use of singlestranded deoxyribonucleic acid as an adsorption column to select closely related genetic units from another organism on complementary ribonucleic acid or deoxyribonucleic acid. Through this deoxyribonucleic acid-agar technique, significant interrelations have been traced among severa varieties of bacteria and also between bacteria and associated viruses (bacteriophages). Preliminary experiments have also shown significant homology, or relation, between deoxyribonucleic acid from human tissues and from the tissues of animals, and the Group believes that these results imply the existence of some common genetic material that has been conserved during the course of vertebrate evolution, including some genetic homology extending from man to fishes. It is believed that the sensitivity of the method can be increased sufficiently to provide new evidence on the most probable line of evolution of the vertebrates from the invertebrates. The Department also supports the work of the Carnegie Committee on Image Tubes for Telescopes, which this year has surmounted previous difficulties with resolving power and uniformity of phosphor screens. The Committee is able to recommend the purchase of 30-80 image tubes of two or three types which will give an advantage of a factor of 10 or more over the direct use of photographic emulsions.

The Department of Plant Biology continued to be concerned mainly with the functional relations and the chemical nature of the various plant pigments that absorb light to supply energy for the various reactions. Measurements of the rate of photosynthesis were made with short light flashes of colours chosen to activate specific pigment systems of algae and a clear separation of the functions of several forms of chlorophyll $a$ was alse achieved. Analysis of accumulated data from long-term genetic and transplant experiments on Achilla and Mimulus with the help of an electronic computer indicated that the principle of genetic coherence which emerged from earlior work on Potentilla is a general one. Biochemical investigations have been started on the key clones of Mimulus cardinalis. An experimental instrument was constructed using an optical range-finder for plane-table mapping in such a way that a point observed through the range-finder telescope is automatically located on the map by an index marker, while the elevation of this point simultaneously appears on a dial and the instrument does all the calculating and plotting.

The Departmont of Embryology reports substantial progress in a large-scale investigation of the metabolism of the early chick embryo. A substantial part was completed of a comprehensive investigation of the normal and abnormal development of the human heart in relation to corrected transpiration of the great vessels. In developmental biology the report records observations on Drosophila, the embryos of the frog, monkey and man, on tumour viruses and interferon, and on rabbits and thalidomide, using techniques of enzymology, immunology and X-ray cinematography. The Genetics Research Unit reports on the work on some idiosyncrasies of phage deoxyribonucleic acid structures, on some further investigations of gene-control systems in maize, and on the preparation of $Z$ protein from ribonuclease and the properties of $Z$ protein. A report from the Cytogenetics Laboratory reviews work on chromosome structure and function, including the progress of spermatogenesis in Drosophila, the histone transition during Drosophila spermiogenesis, and investigations of the xnicrosporogenesis in Tradescantia paludosa, as well as on the incorporation of ${ }^{3} \mathrm{H}$-thymidine in bonds of the great chromosomes of the Drosophila salivary glands.

\section{INTERNATIONAL INDIAN OCEAN EXPEDITION}

T HE Royal Society has issued a preliminary cruise report on the first part of the contribution made by the new R.R.S. Discovery to the International Indian Ocean Expedition*, in which the ships of many nations are making systematic investigations of special problems and areas as well as general surveys. The Discovery's first task was to delimit the area of upwelling off the South Arabian coast during the period of the south-westerly monsoon, and to investigate its mechanism, and the ensuing cycle of chemical and biological changes. The current measurements showed that the predominantly offshore movement at the surface and inshore movement at depths of 100-200 $\mathrm{m}$ could be balanced by a vertical movement of about $4 \mathrm{~m}$ a day near the coast, and this agreed fairly well with the measurements of radiation falling on the surface and of the rise in temperature away from the coast. When the density and pressure distributions are calculated from the hydrographic observations a more complete picture will be obtained. The closely spaced observations show great complexity in detail. Antarctic intermediate water was traced into the Gulf of Aden, where there is a 'reference station' at which all ships will try to make observations. Deep water from the Persian Gulf was detected all along the continental slope

* International Indian Ocean Expedition R.R.S. Discovery. Cruise 1: South-east Arabian Umwelling Region. Pp. 24+15 Figs. (I.ondon: The Royal Society, 1963.) of Arabia, and current measurements in it, at $200 \mathrm{~m}$ and below, showed a predominantly south-westerly movement contrary to the prevailing trend of the surface flow along the coast. Deep water from the Red Sea was very obvious in the Gulf of Aden, but not near the Arabian coast. It appears to take a more southerly direction as will, no doubt, be shown by the observations of other ships.

The richest phytoplankton was found near the coast. particularly between the surface and $20 \mathrm{~m}$. Beyond about 20-30 miles from the coast it was somewhat less and the level of maximum abundance was deeper. The greatest concentration, $64 \times 10^{3}$ cells/l., occurred near the coast at Ras Fartak, and 200 miles offshore surface concentrations were about $3.5 \times 10^{3}$ cells/1. Rates of growth and photosynthesis were measured. The highest concentrations of zooplankton occurred at stations on the continental shelf, but the total amount in the $0-100-\mathrm{m}$ water column was greatest in deep water just off the edge of the sholf. 15-min hauls with a net made to skim the surface and sample the upper $10 \mathrm{~cm}$ of water abeam of the ship took substantial numbers of larvæ similar to the published descriptions of tuna larvæ, many post-larval Carangiid fish, and flying fish. (In the Mediterranean Sea the catches were spoilt by floating oil.) Benthic sampling, done with a grab, was designed specially to investigate the ecology of the very small forms, but the samples also give evidence of fairly rich popula- 